\title{
Quality of ambulatory care provided by physicians-in-training for common diseases before and after the Japanese government reformed post-graduate medical education
}

Yasuaki Hayashino ${ }^{a, b}$, Shunich Fukuhara ${ }^{a}$, Yoshinori Noguchi ${ }^{c}$, Kunihiko Matsui $^{d}$, John W Peabody $^{e}$, Shintaro Okamura ${ }^{b}$, Toshihiko Shimada $^{f}$, Atsushi Miyashita ${ }^{f}$, Makiko Ozaki ${ }^{g}$, Yasuji Arimura ${ }^{h}$, Yohei Fukumoto ${ }^{i}$, Junichiro Hayano ${ }^{j}$, Teruo Ino ${ }^{k}$, Hiroyasu Ishimaru ${ }^{l}$, Hiroshi Fukui ${ }^{m}$, Masayoshi Soma $^{n}$, Yasuhiro Takeuchi ${ }^{o}$, Katsuhiko Shibuya $^{p}$

\author{
${ }^{a}$ Kyoto University Graduate School of Medicine \\ ${ }^{b}$ Department of Endocrinology, Tenri Hospital \\ ${ }^{c}$ Nagoya Daini Red Cross Hospital \\ ${ }^{d}$ Kumamoto University Hospital \\ ${ }^{e}$ Beth Israel Medical Center, NY, USA \\ $f$ Rakuwakai Otowa Hospital \\ $g$ Horikawa Hospital \\ ${ }^{h}$ University of Miyazaki Hospital
}

\author{
${ }^{i}$ Yamaguchi University Hospital \\ ${ }^{j}$ Nagoya City University Medical School \\ ${ }^{k}$ Fujita Health University \\ ${ }^{l}$ Comprehensive Care and Education, Tenri Hospital \\ ${ }^{m}$ Nara Medical University \\ ${ }^{n}$ Nihon University School of Medicine \\ ${ }^{o}$ Toranomon Hospital \\ ${ }^{p}$ Iizuka Hospital
}

The objective of this study is to evaluate the change in the quality of care provided by physicians-in-training in Japan for common diseases after the 2004 post-graduate medical education (PGME) reforms. Physicians who were training at eight Japanese teaching hospitals participated in this study. The physicians completed clinical performance vignettes involving outpatients with four common conditions (diabetes mellitus, chronic obstructive pulmonary disease, vascular disease, and depression). Their responses were judged against a master list of explicit evidence-based quality criteria to give a percentage of correct answers. We compared the scores obtained in 2003 with those recorded in 2008 to evaluate whether they improved after rotating curricula had been put in place. In 2003, 141 (70.1\%) students consented to participate, whereas in 2008, 237 (72.3\%) consented to participate. We did not observe any significant change in the quality of care score after adjusting for possible confounders (change in the total score from $2003=1.9,95 \% \mathrm{CI}:-1.8$ to 5.8 ). The quality of care score improved by 3.1 percentage points at the institutes whose pre-reform curricula were specialtyoriented, which was significantly greater than the 1.4 point increase observed at the institutions whose pre-reform curricula involved rotation ( $\mathrm{p}$-value for interaction, 0.03 ). The quality of care provided by physicians-in-training for diseases that are commonly encountered by general internists did not change after the 2004 PGME reforms.

Keywords: quality of care, medical education, residency training

Received: 2012/6/27 Accepted: 2012/8/28

【Reprint requests】Y. Hayashino, MD, DMSc, MPH

Department of Endocrinology, Tenri Hospital

200 Mishima, Tenri, Nara 632-8552, Japan

\section{INTRODUCTION}

In 2004, the Japanese government introduced a new post-graduate medical education (PGME) program, which aimed to improve the primary care skills of physicians by subjecting them to mandatory rotation through different 
clinical departments. Before this reform, teaching hospitals were free to choose their own PGME curricula. Although some teaching hospitals that were particularly committed to PGME employed a 2-year structured set of rotations through various departments, most medical graduates received their PGME program at a single department of a university hospital, and hence, were trained in specific areas of clinical practice .1,2

In spite of the nationwide reform of the PGME system, there have not been any objective assessments of whether the changes improved the quality of care provided by physicians, although one previous study evaluated the change in the care provided by physicians using a selfreported measure. ${ }^{3}$ Also, no comparison of the quality of care provided by physicians-in-training between the U.S. and Japan has ever been performed, even though the 2004 PGME reforms were performed with reference to the postgraduate medical education system in the U.S.

The objective of this study is to compare the quality of care provided by physicians-in-training for diseases that are commonly encountered by general internists before and after the 2004 medical education system reforms.

\section{METHODS}

\section{Participants}

A convenience sample from 8 Japanese teaching hospitals (with oversampling from the university setting), comprising 5 university-affiliated and 3 non-affiliated teaching hospitals, was used for this study. The same hospital sample was used in both 2003 and 2008. All physicians-in-training who were within 2 years of graduation from medical school were eligible for the study in both periods. The number of eligible physicians was 201 and 326 in 2003 and 2008, respectively. We excluded those who could not take part in the survey because of hospital duties or who did not want to take part. An anonymous self-administered survey involving clinical vignettes was administered at the 8 teaching hospitals before (in 2003) and after (in 2008) the post-graduate medical education system reforms.

\section{Medical education before and after the 2004 PGME reforms}

In Japan, after leaving high school, Japanese medical students enter a medical university for six years. During the last 2 years of their training, medical students usually rotate through all the departments of a university hospital including the operating room, emergency department, and various other departments (clerkship). After graduating from medical school and passing the National Board Examination, the student is certified as a medical doctor (M.D.) and receives a two-year training residency without internship.

The Japanese government reformed the PGME system in 2004 and introduced a new mandatory PGME program. ${ }^{3}$ As part of these reforms, the Ministry of Health, Labour, and Welfare officially implemented 2 major changes to Japan's post-graduate clinical education system. ${ }^{3}$ First, a doctor-to-facility matching system administered by the new Japanese Residency Matching Program was brought into effect. Second, a 2-year-long structured set of rotations became mandatory. This law replaced a 1968 regulation that merely advised graduates to pursue at least 2 years of post-graduate training before setting up an independent practice.

Before these reforms, each teaching hospital adopted one of the following three training styles: (I) Internal medicine, surgery-related subjects, pediatrics, and emergency medicine (at least 2 mo each); (II) Internal medicine and surgery-related subjects, or internal medicine, surgeryrelated subjects, and emergency medicine (at least 2 mo each); (III) Monospeciality; i.e., the traditional Japanese medical education system, under which systematic, structured rotations through various departments in both inpatient and outpatient settings were usually not included, ${ }^{4}$ and the training tended to be skewed by a narrow, longitudinal apprenticeship with a single mentor who was typically a research-trained subspecialist. ${ }^{5-7}$

After the reforms, newly certified physicians must train at teaching hospitals that have been certified by the Ministry of Health, Labour, and Welfare; i.e., university or 
non-university hospitals. During the first 2 post-graduate years, Japanese physicians-in-training rotate through 7 specialties (internal medicine, surgery, emergency medicine or anesthesiology, pediatrics, psychiatry, communitybased medicine, and obstetrics and gynecology), spending at least 6 months in the internal medicine department. The new program was designed to provide various clinical opportunities to residents that would allow them to obtain primary care skills and knowledge and to improve the working conditions of residents, including their salary and working environment.

\section{Measurement method}

In both the 2003 and 2008 surveys, we gathered information on the post-graduate education curricula employed at the participating hospitals, including the hours allocated to internal medicine training and the type of curriculum employed (a monospeciality-oriented or rotating curriculum), from the chief of the Department of Medical Education at each hospital. Quality care was defined as the delivery of patient care in a manner that leads to better outcomes for individuals and populations. ${ }^{8}$ Clinical vignettes can be used to measure variations in care quality. We used such vignettes to prompt open-ended responses to questions that were arranged in sections to re-create the sequence of a typical patient visit: the initial presentation of the problem, an examination of the patient's clinical history, physical examinations, radiological or laboratory tests ordered, diagnosis, and treatment plan. Each section began with the presentation of new patient information gained from the answers to the questions in the previous section. After answering a section and moving on to the next, the physicians could not return to the previous section to revise their answers. Thus, they could not use the new information to change (and improve) their previous answers. Although vignettes are not the same as actual clinical practice, they have been validated as a measure of clinical practice in two prospective studies, which used the 'gold standard' of unannounced standardized patients (SP), who were played by experienced actors that typically worked in SP medical education pro- grams. ${ }^{9} 10$ The scores derived from such vignettes reliably reflect actual levels of physician practice, and hence, display higher criterion validity than scores derived from chart abstractions. As per international practice, the participants were given 15 minutes to complete each of the 4 clinical performance vignettes.

We began by selecting four common outpatient chronic conditions (diabetes mellitus, chronic obstructive pulmonary disease, vascular disease, and depression) based on their prevalence in Japan. Two detailed clinical vignettes were developed for each chronic condition, giving a total of 8 vignettes. These vignettes were originally developed to measure care quality in the United States. ${ }^{9}$ The vignettes were translated into Japanese and partly revised to match clinical practice in Japan, for example, the use of equivalent drugs and screening procedures. ${ }^{11}$

To avoid potential bias caused by the training duration of the students, the survey was administered on the same day at all institutions in both 2003 and 2008.

\section{Scoring}

The responses to the vignettes were scored by the authors. To ensure consistency during the scoring, each condition was scored by the same author. With regard to chronic conditions, we used the scoring criteria developed by the original American authors, who based their criteria on international guidelines. 9 These criteria were then reviewed and ratified by expert panels of academic and community physicians in Japan, who belonged to fields relevant to each condition. As a result, the original criteria were adopted. To verify that the Japanese version of the survey was equivalent to the original English version, the 8 vignettes were translated back into English and verified by the original American authors. Based on their recommendations and consensus among the authors, the vignettes and scoring criteria were finalized. The vignettes contained a mean of 37 criteria (range $=26-50$ ). Each criterion was rated according to a three-level quality-of-care scale: adequate, unnecessary, or inappropriate care. One point was given for each criterion for which adequate care was proposed. An overall vignette score 
was assigned by summing the scores for the individual criteria.

\section{Analyses}

Main Analysis

Categorical data were described using percentages. First, we drew a bar graph indicating the mean scores of the physicians-in-training in Japan in 2003 and 2008. Next, we compared the total scores of the Japanese physicians between 2003 and 2008 using linear regression models and robust variance estimates that took within-facility clustering into account and adjusted for the number of postgraduation years (PGY) and the type of vignette. We produced adjusted means and $95 \%$ CI by adjusting their errors to account for the clustering within each facility. We also used linear regression analysis to assess the interaction between test year and the number of PGY. Finally, the scores for each of the 4 vignettes (diabetes mellitus, chronic obstructive pulmonary disease, vascular disease, and depression) were compared between 2003 and 2008. Exploratory analysis

We also examined whether the effects of the PGME reforms differed depending on an institution's pre-reform curriculum type (monospeciality-oriented or rotating curriculum). Interaction term analysis was used to examine the difference in the relationship between the quality score and the 2004 PGME reforms between hospitals with monospeciality-oriented curricula and those with rotating curricula. The two-sided alpha level was set at 0.05 . The analyses were performed using commercially available software (Intercooled STATA 10.0; STATA Corporation, TX, USA). Ethics approval was granted for this study by the Kyoto University Faculty of Medicine Institutional Review Board.

\section{RESULTS}

In 2003, of all the eligible physicians-in-training, 141 (70.1\%) consented to participate in the present study, whereas in 2008, 237 (72.3\%) of the eligible physicians consented to participate (Table 1). Two-thirds of the participants (66.0\% in 2003 and $74.3 \%$ in 2008) worked in university-affiliated hospitals, and the rest worked in nonuniversity-affiliated teaching hospitals. Of the 8 hospitals, 3 hospitals employed monospeciality-based educational systems in 2003, and all of the hospitals' curricula

Table 1. Demographic characteristics of the participants and participating hospitals in 2003 and 2008

\begin{tabular}{|c|c|c|}
\hline & 2003 & 2008 \\
\hline \multicolumn{3}{|l|}{ No. of each hospital type } \\
\hline University hospital & & 5 \\
\hline Non-university hospital & & 3 \\
\hline \multicolumn{3}{|c|}{ No. of participants stratified according to post-graduate year ( $\%$ of total) } \\
\hline All & 141 & 237 \\
\hline Post-graduation y ear 1 & $87(62.8 \%)$ & $130(54.9 \%)$ \\
\hline Post-graduation y ear 2 & $54(37.2 \%)$ & $107(45.1 \%)$ \\
\hline \multicolumn{3}{|l|}{ No. of participants stratified according to hospital type (\% of total) } \\
\hline University hospital & $93(66.0 \%)$ & $176(74.3 \%)$ \\
\hline Non-university hospital & $48(34.0 \%)$ & $61(25.7 \%)$ \\
\hline \multicolumn{3}{|l|}{ Type of curriculum } \\
\hline Monospeciality system & 3 & 0 \\
\hline Super-rotation system & 5 & 8 \\
\hline Duration of internal medicine training relative to that in 2003 & $100 \%$ & $63.3 \% \quad(50-90 \%)$ \\
\hline Participation rate ( $\%$ of eligible) & 70.1 & 72.3 \\
\hline
\end{tabular}


were based on a super-rotation system in 2008. In 2003, rotating to the psychiatry department was not mandatory in any of the participating hospitals. Crude overall total scores, as well as total scores for each PGY, stratified according to the study year, are shown in Figure 1. The crude overall total scores improved from $41.9 \%$ (SD $=$ $0.092)$ in 2003 to $44.0 \%(\mathrm{SD}=0.088)$ in 2008 , and the difference was significant $(P=0.023)$. Figure 2a shows the changes in the overall total scores and the total scores for PGY 1 and 2 between 2003 and 2008 after adjusting for PGY and/or the type of vignette. After adjusting for PGY and the type of vignette and considering the clustering within each facility, we did not observe any significant improvement in the overall total score (change in total score from $2003=1.9,95 \% \mathrm{CI}-1.8$ to 5.8 ) or those of PGY 1 (change in total score from $2003=0.8,95 \% \mathrm{CI}$ -2.5 to 4.1 ) or PGY2 (change in total score from $2003=$ $3.5,95 \% \mathrm{CI}-2.5$ to 9.5 ). Figure $2 \mathrm{~b}$ shows the changes in the overall total scores and the scores for each disease between 2003 and 2008 after adjusting for the type of vignette and PGY. Of the 4 diseases, we only observed a significant improvement in the score for the diabetes vignette, which displayed a 7.8 percentage point (95\% CI, 3.1 to 12.4 ) improvement after adjusting for the type of vignette and PGY. We observed a non-significant improvement in the score for depression (2.1 percentage points; $95 \% \mathrm{CI},-1.2$ to 5.3 ).

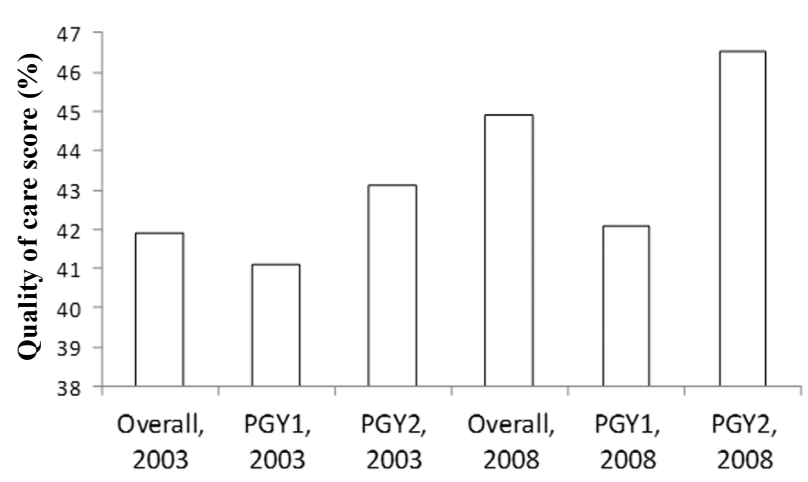

Figure 1. Direct comparison of the overall scores, and the scores for each post-graduation year, of physicians-in-training

PGY, post-graduation years

* P-values were subjected to the Sidak adjustment for multiple comparisons.
A

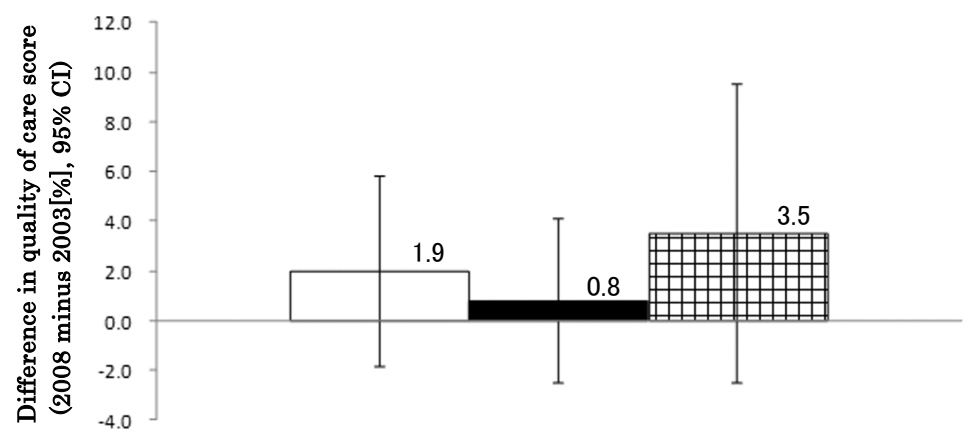

$\square$ Overall $\square \mathrm{PGY} 1 \mathrm{P} \mathrm{PGY} 2$

B

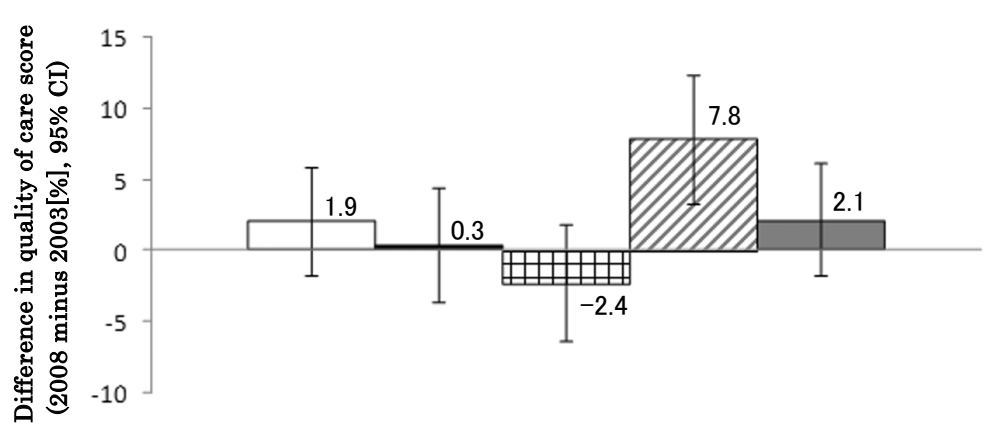

Figure 2 . Difference in the quality of care scores of Japanese physicians-in-training between 2003 and 2008

Panel A: Difference in the total scores for the whole sample or each PGY between 2003 and 2008.

Panel B: Difference in the total scores for the whole sample or each disease between 2003 and 2008. Differences are adjusted for PGY and vignette subtype in each disease. COPD, chronic obstructive pulmonary disease 
Table 2. Results of stratified analysis according to pre-reform curriculum type

\begin{tabular}{|c|c|c|}
\hline & Difference in quality of care score & $P$-value for interaction \\
\hline \multicolumn{3}{|l|}{ Total score } \\
\hline Rotation sy stem in 2003 & $1.4(-3.93-6.73)$ & \multirow{2}{*}{0.030} \\
\hline Monospeciality system in 2003 & $3.1(-0.31-6.44)$ & \\
\hline \multicolumn{3}{|l|}{ Vascular disease } \\
\hline Rotation system in 2003 & $-1.3(-5.62-5.83)$ & \multirow{2}{*}{0.120} \\
\hline Monospeciality system in 2003 & $3.6(-1.12-3.02)$ & \\
\hline \multicolumn{3}{|l|}{ COPD } \\
\hline Rotation system in 2003 & $-2.2(-8.33-4.01)$ & \multirow{2}{*}{0.025} \\
\hline Monospeciality system in 2003 & $-3.0(-5.40--0.51)$ & \\
\hline \multicolumn{3}{|l|}{ Diabetes } \\
\hline Rotation system in 2003 & $7.6(0.62-14.58)$ & \multirow{2}{*}{$<0.001$} \\
\hline Monospeciality system in 2003 & $8.1(6.25-10.01)$ & \\
\hline \multicolumn{3}{|l|}{ Depression } \\
\hline Rotation system in 2003 & $1.3(-3.26-5.83)$ & \multirow{2}{*}{0.157} \\
\hline Monospeciality system in 2003 & $3.6(-1.76-8.89)$ & \\
\hline
\end{tabular}

COPD, chronic obstructive pulmonary disease

The results of our exploratory analysis of the change in the quality score stratified according to the type of prereform medical education curriculum employed are shown in Table 2. The change in the quality score was greater in the hospitals in which monospeciality-oriented curricula were employed in 2003 than in those that used rotating curricula ( $p$-value for interaction $=0.030)$. Of all the clinical vignettes, the change in the quality score for diabetes care was significantly greater in the hospitals in which monospeciality-oriented curricula were employed in 2003 ( $p$-value for interaction $<0.001$ ).

\section{DISCUSSION}

We did not observe any significant improvement in the quality of care in Japan from 2003 to 2008. So, why did the quality of care scores for the diseases that we examined, which are commonly encountered by general internists, not improve despite the large-scale medical education reforms enacted in 2004? One possible reason is that different ministries are responsible for undergraduate (the Ministry of Education, Culture, Sports, Science, and Technology) and post-graduate medical education (the Minis- try of Health, Labour, and Welfare); thus, there is no continuum between the medical education provided before and after graduation from medical school. Secondly, although the framework of the medical education system was changed, there was little change in the skills base of medical educational facilities or the incentives for physicians to teach clinical medicine. Thus, without tackling this issue, changing the medical education framework might not work. Thirdly, the 2004 medical education reforms only intended to change the framework of postgraduate education in hospital settings and did not attempt to improve ambulatory care competency. A previous report suggested that the quality of acute care improved after the reforms ${ }^{12}$; however, in an era when the majority of healthcare is provided in an ambulatory setting, shifting the setting in which medical education is offered to an ambulatory setting might be necessary.

In our exploratory analysis, which was stratified according to the pre-reform medical education system employed, we found that the extent of improvement in the quality score was greater in hospitals in which the prereform system was monospeciality-oriented, which seems 
reasonable. The medical education curricula in these hospitals (most of them were university-affiliated hospitals) usually did not include systematic, structured rotations through various departments in both the inpatient and outpatient settings. ${ }^{4}$ Second, the training at these institutions tended to be skewed by a narrow, longitudinal apprenticeship with a single mentor who was typically a research-trained subspecialist. ${ }^{5-7}$ Therefore, our finding that the change in the quality score differed between institutions with monospeciality-oriented and rotating pre-reform education systems might be explained by the extent to which the medical education systems of these two types of institutions changed.

The number of people who committed suicide in Japan in 2010 remained above 30,000 for the 12 th consecutive year. Depression is one of the most common psychiatric diseases and a known cause of suicide; thus, one of the key features of the 2004 PGME reforms was the introduction of mandatory rotation to a psychiatry department to improve the quality of depression care; however, the quality of depression care did not improve after the reforms. There are several possible reasons that might explain this result. First, most psychiatric training occurs in an inpatient setting, and even in hospitals that offer outpatient psychiatry training patients are usually referred from other departments and have relatively severe problems. In addition, the duration of training in psychiatry departments is very short (usually 1 month, rarely 2 months). In such circumstances, it is hard to obtain the basic mental healthcare skills that are needed in primary care settings, such as diagnosing mental health problems in patients who also have physical problems, even if rotating to psychiatry departments is mandatory. Second, most of the medical trainers from departments other than psychiatry would not have received any post-graduate training on mental health problems. In fact, depression is often under-diagnosed in the primary care setting in Japan. ${ }^{13}$ Physicians-in-training thus have little chance to receive training on less severe mental health problems outside of psychiatry departments. In the near future, we ex- pect that trainers who have not been educated about mental health problems will be replaced by those who are more conscious of mental health problems, and thus, the quality of mental healthcare training will improve.

We observed a significant improvement in the quality of diabetes care in our study. ${ }^{14}$ However, our data did not indicate the reason for this result. One possibility is the increasing number of diabetes patients in Japan, which has risen from 6.9 million to 8.9 million over the past decade. Thus, physicians are more likely to encounter diabetes patients during their training, which might have led to the observed improvement in the quality of diabetes care. Thus, we speculate that this improvement might not have been due to the 2004 PGME reforms.

There are several limitations to this study. First, because the study involved observational comparisons between the pre- and post-PGME reform eras, our results might have been influenced by changes other than the 2004 reforms. Second, our results might not accurately represent the quality of care delivered by physicians-in-training in Japan because we used a convenient sample of Japanese educational hospitals.

In conclusion, the quality of ambulatory care provided by physicians-in-training for common diseases did not improve after the 2004 PGME reforms. In addition, medical education programs at university hospitals might place insufficient emphasis on ambulatory and general care. Medical education trainers should be more conscious of care quality when teaching physicians-in-training.

\section{REFERENCES}

1. Teo A. The current state of medical education in Japan: a system under reform. Med Educ 2007;41(3):302-308.

2. Otaki J. Considering primary care in Japan. Acad Med 1998;73(6):662-668.

3. Nomura K, Yano E, Aoki M, et al. Improvement of residents' clinical competency after the introduction of new postgraduate medical education program in Japan. Med Teach 2008;30(6):e161-169.

4. Ohtaki J, Fujisaki K, Terasaki H, et al. Specialty choice 
and understanding of primary care among Japanese medical students. Med Educ 1996;30(5):378-384.

5. Tajima Y, Nagasawa Z, Tanabe I, et al. Education as a means of reducing medical expenses. Med Educ 1999;33(2):145153.

6. Gillespie CA, Gillespie HE, Carr JE. Contrasts between Japanese and American medical education and clinical practice. Mil Med 1984;149(7):393-396.

7. Noble KK, Miyasaka K, Takayama JI. Pediatric postgraduate medical education in Japan and the United States: A comparative study. Journal of the Japan Pediatric Society 2004;108:1299-1307.

8. Lohr KN. Medicare: A Strategy for Quality Assurance. Washington, DC: National Academy Press; 1990.

9. Peabody JW, Luck J, Glassman P, et al. Comparison of vignettes, standardized patients, and chart abstraction: a prospective validation study of 3 methods for measuring quality. Jama 2000;283(13):1715-1722.

10. Peabody JW, Luck J, Glassman P, et al. Measuring the quality of physician practice by using clinical vignettes: a prospective validation study. Ann Intern Med 2004; 141(10):771-780.

11. Hayashino Y, Fukuhara S, Matsui K, et al. Quality of care associated with number of cases seen and self-reports of clinical competence for Japanese physicians-in-training in internal medicine. BMC Med Educ 2006;6:33.

12. Tokuda Y. Reseach of developing continuum medical education system across undergraduate, post graduate, and specialty training.;2010.

13. Yamada K, Maeno T, Waza K, et al. Under-diagnosis of alcohol-related problems and depression in a family practice in Japan. Asia Pac Fam Med 2008;7(1):3.

14. 厚生労働省健康局総務課生活習慣病対策室. 平成19年 国民健康・栄養調査結果の概要. 2009. 


\section{4 年の卒後臨床研修必修化前後における 初期研修医の外来診療の質の比較}

林野泰明 ${ }^{a, b}$, 福原俊一 ${ }^{a}$, 野口善令 ${ }^{c}$, 松井邦彦 ${ }^{d}$, John W Peabody ${ }^{e}$, 岡村真太郎 ${ }^{b}$, 島田利彦 ${ }^{f}$, 宮下 淳 $f$, 小崎真規子 ${ }^{g}$, 有村保次 ${ }^{h}$, 福本陽平 ${ }^{i}$, 早野順一郎 ${ }^{j}$, 井野晶夫 ${ }^{k}$, 石丸裕康 ${ }^{l}$, 福井 博 $m$, 相馬正義 ${ }^{n}$, 竹内靖博 $o$, 渋谷克彦 $p$

$a$ 京都大学大学院 医学研究科

$b$ 天理よろづ相談所病院 内分泌内科

$c$ 名古屋第二赤十字病院 総合内科

$d$ 熊本大学医学部附属病院 総合臨床研修センター

${ }^{e}$ Beth Israel Medical Center, NY, USA

$f$ 洛和会音羽病院 健診センター

$g$ 堀川病院 内科

$h$ 宮崎大学医学部附属病院 卒後臨床研修センター
${ }^{i}$ 山口大学病院 総合診療部

$j$ 名古屋市立大学大学院 医学研究科

$k$ 藤田保健衛生大学 一般内科

$l$ 天理よろづ相談所病院 総合診療教育部

$m$ 奈良県立医科大学 卒後臨床研修センター

${ }^{n}$ 日本大学医学部附属板橋病院 総合内科

$o$ 虎の門病院 医学教育部

$p$ 飯塚病院 総合診療科

本研究の目的は，2004年の卒後医学教育改革前後の医療の質を比較することである. 日本の 8 つ臨床研 修指定病院において研修中の医師が本研究に参加した。参加した医師は，外来において頻度の高い疾患（糖 尿病，慢性閉塞性肺疾患，心血管疾患，うつ病）についての臨床シナリオに回答した. 回答をエビデンスに 基づいた診療の質の基準に照らしあわせて採点し, 正答率スコアを算出した. ローテート研修が導入された 前後でスコアの変化が生じたかを検証するために, 2003年の参加者のスコアと, 2008年の参加者のスコアを 比較した。 2003 年では，141名 (70.1\%)が，2008年には 237 名 $(72.3 \%)$ が参加に同意した。交絡因子を調整後 も，両年の間にスコアの違いを認めなかった (2003 年からのスコアの変化 $=1.9 \% .95 \% \mathrm{CI}-1.8$ to $5.8 \%$ ). 教育 改革前の研修プログラムがストレート研修の施設ではスコアが $3.1 \%$ 改善しており，改革前にローテート研 修を採用していた施設の改善度 $1.4 \%$ と比較して有意に高值であった。全般的には，2004年の医学教育改革 前後において, 研修医の医療の質は変化していなかった。

キーワード：医療の質, 医学教育, 初期研修 